\title{
PARAllelistlik poeetika
}

\author{
Arne Merilai, Maria-Kristiina Lotman
}

Asudes koostama Methise poeetika erinumbrit, seadsime toimetajatena endale ja võimalikele autoritele ülesandeks esindada kunstiliikide ja erialade mitmekesisust. Ei ole ju poeetika ainult ilukirjanduse pärusmaa, vaid sügavalt juurdunud juba igapäevakeeles endas. Ent poeetika hõlmab ka teatri- ja filmikeelt, mõjutab reklaamikunsti ning filosoofilist ja poliitilist retoorikat, muusika või kujutava kunsti komponeerimise ning interpreteerimise seadustest kõnelemata.

Tulemus, nagu sisukorrast näha, sai paraku siiski sõnakunstikeskne, kuid võrdleva poeetika potentsiaali maksab edaspidi kahtlemata silmas pidada. Siiski - virgutavat erinevust ja üleskutset dialoogile leiab numbrist parasjagu, igast artiklist: esindatud on teoloogia, folkloristika, klassikaline filoloogia, eesti kirjanduslugu ja kirjandusteooria, lingvistika, narratoloogia, tõlketeooria, ajalugu ning kultuurisemiootika. Enamiku käsitluste ühendava joonena tõuseb siiski esile parallelismi mõiste. See ei tohiks meid imestama panna, sest tegu on kahtlemata poeetika tuumaga. Mitmekesiste parallelisminähtuste ümber kallerdub ka kogu teoreetiline süsteem, mille aluste kirjeldamise eest oleme tänu võlgu vene ja maailma vormikoolkondadele, uuskriitikutele ning lingvistidele, Aristotelestele ja Boileau'dele, Roman Jakobsonidele, Gérard Genette'idele ning Juri Lotmanitele... Mida uut aga ütlevad meie köite autorid?

Urmas Nõmmiku artikkel avab piiblitekstide poeetilist struktuuri, andes ülevaate põhilistest ühikutest, millest piiblivärss üles ehitatakse. Enamasti rajaneb vanatestamentlik luule bi- ja trikoolonitel ehk kaksik- või kolmikvärssidel kui aspektilistel mõttekordustel. Nende parallelismide alusel luuakse mahukamaid alastroofe, liidetakse kokku stroofe ja poeeme. Ornamentaalses funktsioonis kasutatakse mitmesuguseid stiilivõtted (nt ellips ja kiasm) ning rikkalikke kõlamänge alates algriimist ja anakruusist. Piibliluulet iseloomustab intensiivne regulaarsus ehk kõikvõimalike stiili-, vormi-, lauseehituse võtete rütmiline kordumine ja afektiivne kuhjumine. Samas iseloomustab seda luulet ka püüd regulaarsusest vabaneda ehk vabavärsistuda. Jesaja 24,6-13 näitel demonstreerib Nõmmik, kuidas teose väljendusplaan on lahutamatult seotud selle sisuga: ilma esimest mõistmata jääb ka teise tõlgendus puudulikuks. Piibliluule ei sarnane tänapäevase lüürilise eneseväljendusega, vaid on ekspressiivne ja direktiivne funktsionaaltekst - värvikate ja drastiliste võrdpiltidega kujundirikas mõjutusvahend.

Mari Sarv määratleb regivärsis kanoonilise, kogu teksti läbivalt kujundava parallelismitüübi, kohaldades selleks Juhan Peegli regivärsi poeetilise sünonüümia definitsiooni. Nimelt katab poeetiline sünonüüm Peegli sõnul laulu kontekstis põhisõnaga täpselt sama tähendusvälja. Sellises parallelismis esinevad kõrvutatud sõnad või fraasid samatähenduslikena ja sünonüümsetena, isegi kui nad tavakõnes võivad olla vastandlikud. Sarv järeldab, et 
seda tüüpi parallelism on üks regivärsi peamisi tunnuseid, kusjuures parallelismi elementide valiku ja kombineerimise värssidesse määravad algriim ja värsimõõt.

Janika Päll, kes küll parallelisminähtusi lähemalt ei tematiseeri, käsitleb oma artiklis Tallinna ja Tartu varauusaegsete kreekakeelsete luuletekstide poeetikaga seotud probleeme, näidates, kuidas siingi on sisu ja vorm lahutamatult seotud: vorm võib viidata ajastule, žanrile, aga ka konkreetsematele temaatilistele struktuuridele. Iga poeetilise teksti tõlkija seisab valiku ees: kas tõlke dominandiks saab sisu- või väljendusplaan. Päll esindab kõrgstiilset seisukohta, mille järgi on sõnakunsti vormiline struktuur liiga oluline ja meie kultuuriruumis nii sügavalt juurdunud, et sellele lähenemisest tõlkes loobuda. Praktiliste näidete abil demonstreerib ta värsivormilise tôlkestrateegia efektiivsust humanistlike kreekakeelsete luuletekstide eestindamisel.

Tanar Kirsi artikkel on pühendatud Juhan Liivi käsikirjalisele poeetikakäsitusele. Ta näitab, et Liiv on oma luuleteostes lähtunud väga kindlatest esteetilistest põhimõtetest ning tema meetod on olemuselt selge, läbimõeldud ja järjepidev. Kirs toob esile, et Juhan Liiv lähtub selgelt veel formalismieelsest ettekujutusest, mille järgi on vorm üksnes kirjandusteose passiivne ja muutumatu välispind. Sellegipoolest tuleb välja, et ehkki Liivi teoreetiline vormimääratlus näib kitsas, lähtub ta oma arutlustes märksa avaramast arusaamast, mis tuleb ta oma õnnestumiste praktikast. Noor uurija võtab kokku, et Liivi meetodit võib ennekõike nimetada lihtsuse või vaesuse poeetikaks ning tema kunstiline programm seisneb teadlikus püüdlemises lihtsate asjade kujutamisele lihtsas väljenduses. Sõna juures oli Liivile esmane aktiivne, helisev ja plastiline sisu, meeleliselt tajutav ainuline referents, osutus, mitte kehade varjud või helide kajad kui teisesed, konkreetsusest eemalduvad abstraheerivad jäljed (objektkeele koopiad). Teksti tasandil pidas ta aga tähtsaks kogu ülesehituse kooskõlalist tervikut, kompositsioonilist autoreferentsi. Sarnasele tulemusele jõuavad hiljem ju ka formalistid ja strukturalistid. Väljapuhastatud ning liigsõnalisusest vabastatud lihtne pilt ehk sõnastuste kontrastne, analüütiliselt kõrvutav iseseisvus - lahutamine - ühelt poolt ning rütmi koostoimeline sünteetilisus - ühendamine - teiselt poolt on printsiibid, mis juhatavad Liivi tema luuletemplini.

Ka Michelle Mueller lähtub poeetika ürgeeldusest, et luule aluseks on mitmetasandilised kordused. See tähendab formaalsete ja semantiliste ekvivalentide kõrvutamist ning vastandamist, mis on keelekasutuse poeetilise funktsiooni tuumaks. Ta käsitleb kordusi ja parallelismi kui väljapaistvaid esiletõstmise ja harjumuse võõritamise võtteid Betti Alveri luules, näidates kahe juhtumiuuringuga nende rajavat rolli Alveri stiilis. Artiklis analüüsitakse, kuidas Alver mõtestab häälikukordusi, grammatilist parallelismi ja deiktilisi vastavusi oma luuletuste poeetilises struktuuris, nii et kordused hakkavad osalema tähendusloomes, vorm hakkab looma sisu ja sisu vormi. Toimetus otsustas jätta Muelleri kaastöö eesti keelde tõlkimata, kuivõrd selle ingliskeelne mõistevõrk omandab ülikooli poeetikaseminaride jaoks õppevahendi kaalu. 
Külliki Kuuse artikkel käsitleb Uku Masingu poeetikat. Kuusk näitab, et ka Uku Masingu luules ja metafooriloomes on peamine kooshoidev võte parallelism, mis seob tema luule ühelt poolt folkloorse traditsiooniga, teiselt poolt aga ka piibliluulega. Just parallelismi kaudu tuleb Kuuse sõnul esile nii Masingu luule boreaalne isikupära kui ka avaram boreaalne vaimsus, mille Iõimumist vanatestamentliku ning kristliku vaimsusega väljendab ka tema algupärane kujundiloome.

Jaak To mbergi artikkel tõendab, kuidas narratiivi poeetilise struktuuri analüüs aitab mõtestada teksti ja avada teistele lähenemisviisidele märkamatuks jäänud tähendustasandeid. Seni on J. G. Ballardi „Crashi“ tôlgendatud vastuoluliselt - ühelt poolt kui klassikalist hoiatusromaani vanas heas allegoorilises võtmes, teisalt aga kui stiilselt ükskõikset tehnoloogilise võõrdumise kirjeldust. See on tekitanud kriitikas seni lepitamatu vastuolu romaani moraalse sõnumi osas: kas tegemist on kujundliku düstoopilise moralitee või vastuoksa tehnilise ja hingetu perversiooni uue tasemega. Tomberg esindab „kirjanduse lepitavat otstarvet“ ja panustab romaani põhimõttelisele kahemõttelisusele, mis ei välista kumbagi vaatepunkti. Ta möönab ühtaegu nii hinnanguliselt hukkamõistvat kui ka ükskõikselt „moraalitut“ tõlgendust. Vaidlus laheneb teksti eri kirjeldustasandite kontrapunktilises parallelismis: neutraalselt loetleva kujutamise ehk näitava registri ülekaal sisendab indiferentsust, sellal kui jutustaja registri modaalsus ja tegelaste afektiivsus sisendab varjatult hoiakulist distantsi.

Anne Lange ja Miriam Mcllfatrick-Ksenofontovi artikkel on pühendatud tõlkepoeetikale ja tegeleb eeskätt luuletõlkimise probleemidega, näitlikustades ühe Jaan Malini dadaistliku keeleluuletuse tõlkeprotsessi kirjelduse kaudu tõlkija valikuid ja väljakutseid. Tõlkija ülesanne on mõista lähteteksti tähenduslikult olulisi omadusi, mis tagavad luuleteksti terviklikkuse, ning leida sihtkeelest analoogilisi väljendusvõimalusi nende omaduste markeerivaks edasiandmiseks. Selline meetod on aktiivselt kaasaloov, kuigi konkreetne tulemus näib tõlkija enda arvates olevat originaalist analüütilisem.

Teooriavahenduse rubriigis esitatakse Maria-Kristiina Lotmani kommenteeritud tõlkes Juri Lotmani entsüklopeediline artikkel „Värss ja proosa“. Selles bibliograafiate eest varjule jäänud konspektis käsitletakse olemuslikult värsi ja proosa kujunemislugu, struktuurseid omadusi ja vastassuhteid. Kultuurisemiootika rajaja näitab, kuidas periooditi võivad värss ja proosa olla teineteist funktsionaalselt täiendavad, teisalt aga ka omavahel läheneda, nii et proosa omandab värsilisuse jooni, värss aga omakorda proosapärastub. Eesti kirjanduse lähiajaloos võime mõlemaid protsesse selgekujuliselt jälgida. Värsskõne võime säilitada ja tekitada tavakõnega võrreldes rohkem informatsiooni on Juri Lotmani sõnul eelduseks, miks keelekasutuse poeetilist funktsiooni realiseeriv luulekeel ei kadunud kultuurimälust ka pärast kirjakultuuri tekkimist, vaid muutus sõnakunsti tunnuseks, uue informatsiooni loojaks ning ühisteadvuse tähtsaks tunnetusvahendiks. Ilukirjanduslik proosakeel tekib aga alles luulekeele järel, vastandudes ühtlasi nii sellele kui ka teisalt argikeele proosale. Seega kasutab 
ilukirjanduslik proosa luule taustal miinusvõtteid: olemata ise olmeproosa, ta samal ajal matkib seda.

Seekordseks filoloogiliseks, kultuuri- ja mentaliteedilooliselt väärtuslikuks arhiivileiuks on Kristi Viidingu tõlgitud ja toeka eessõnaga varustatud Johannes Hörnicki ladinakeelne traktaat „Luulekunsti ülistus“ (1671), mis on kolmest Eesti- ja Liivimaal avaldatud varauusaegsest poeetikast kõige mahukam. Esmalt antakse ülevaade piirkonna varasematest ladinakeelsetest poeetikakäsitlustest. Hörnicki hüperboolne euloogia ei olnud mõeldud õppematerjaliks ega käsiraamatuks, vaid see on inauguratsioonikõnena esitatud esseistlik kirjutis, mis kiidab barokse ülevoolavusega voorusliku luulekunsti ülikasulikku meeldivust. Enne idealistliku esteetika ja lingvistilis-strukturalistlike vormikoolkondade sündi oli selletaoline moralistlik-praktiline õigustamine valdav, mis näib ühtlasi intuitiivselt ennetavat hilisemat arusaama, et figuratiivse ilukõne olemus peitub kuskil keele eripärases kasutamises ehk keelepragmaatikas. Akadeemilise Tallinna ja Tartu kreeka- ning ladinakeelse humanistliku luulemõtte taasavastamine Janika Pälli ja Kristi Viidingu tänuväärsel, teineteist täiendaval vahendusel rikastab oluliselt meie euroopalikku kultuuriteadvust.

Poeetilise praktika teoreetilises mõtestamises on inimkond päris kaugele arenenud. 